\title{
Advanced and Intensified Seawater Flue Gas Desulfurization Processes: Recent Developments and Improvements
}

\author{
Nguyen Van Duc Long ${ }^{1, *,+}$, Dong Young Lee ${ }^{1,+}{ }^{+}$Kim Myung Jin ${ }^{2}$, Kwag Choongyong ${ }^{2}$, \\ Lee Young Mok ${ }^{2}$, Lee Sung Won ${ }^{2}$ and Moonyong Lee ${ }^{1, *(1)}$ \\ 1 School of Chemical Engineering, Yeungnam University, Gyeongsan 712-749, Korea; ldy5525@ynu.ac.kr \\ 2 Hanbal Masstech Ltd., Golden Root Complex, Gimhae 50969, Korea; mjkim@hanbalmasstech.com (K.M.J.); \\ cykwag@hanbalmasstech.com (K.C.); ymlee@hanbalmasstech.com (L.Y.M.); \\ swlee@hanbalmasstech.com (L.S.W.) \\ * $\quad$ Correspondence: allenthelong@yu.ac.kr (N.V.D.L.); mynlee@yu.ac.kr (M.L.); Tel.: +82-53-810-3241 (N.V.D.L.); \\ +82-53-810-2512 (M.L.) \\ + These two authors contributed equally to this work.
}

Received: 12 October 2020; Accepted: 11 November 2020; Published: 13 November 2020

check for updates

\begin{abstract}
Seawater flue gas desulfurization (SWFGD) is considered to be a viable solution for coastal and naval applications; however, this process has several drawbacks, including its corrosive absorbent; low vapor loading capacity since the solubility of sulfur oxides $\left(\mathrm{SO}_{\mathrm{x}}\right)$ in seawater is lower than that of limestone used in conventional methods; high seawater flowrate; and large equipment size. This has prompted process industries to search for possible advanced and intensified configurations to enhance the performance of SWFGD processes to attain a higher vapor loading capacity, lower seawater flowrate, and smaller equipment size. This paper presents an overview of new developments as well as advanced and intensified configurations of SWFGD processes via process modifications such as modification and optimization of operating conditions, improvement of spray and vapor distributors, adding internal columns, using square or rectangular shape, using a pre-scrubber, multiple scrubber feed; process integration such as combined treatment of $\mathrm{SO}_{x}$ and other gases, and waste heat recovery; and process intensification such as the use of electrified sprays, swirling gas flow, and rotating packed beds. A summary of the industrial applications, engineering issues, environmental impacts, challenges, and perspectives on the research and development of advanced and intensified SWFGD processes is presented.
\end{abstract}

Keywords: marine seawater FGD process; process integration; process intensification; process modification; process improvement

\section{Introduction}

The global energy demand is increasing rapidly, leading to the construction of many power plants using fossil fuel [1]. Combustion of fossil fuel such as coal and/or oil in these plants increases the amount of sulfurous oxides $\left(\mathrm{SO}_{\mathrm{x}}\right.$, whereof the main constituent is sulfur dioxide $\left.\left(\mathrm{SO}_{2}\right)\right)$, which has a negative impact on human health and the environment [2]. Consequently, tight $\mathrm{SO}_{\mathrm{x}}$ emissions regulations have been promulgated in many countries [3].

Furthermore, marine shipping accounting for more than $90 \%$ of international trade [4] generates substantial $\mathrm{SO}_{\mathrm{x}}$ emissions [5]. To prevent the formation of $\mathrm{SO}_{\mathrm{x}}$, the International Marine Organization (IMO) approved sulfur emissions regulations [6]. From 1 January 2015, equivalent sulfur emissions need to be lower ( $0.1 \%$ in weight) in some coastal regions termed as "Sulphur Emission Control Areas" 
(SECAs). From 1 January 2020, sulfur emissions for ocean ships worldwide must be equivalent to that emitted by fuel with sulfur content lower than $0.5 \%$ in weight [7].

To effectively control $\mathrm{SO}_{2}$ emissions, flue gas desulfurization (FGD), in which the flue gas interacts with an absorbent medium, is a viable solution [8], with wet processes occupying roughly $87 \%$ of the worldwide share [9]. Wet scrubbers can be classified as wet limestone FGD, wet lime and magnesium-lime FGD, seawater FGD (SWFGD), dual-alkali FGD, and ammonia FGD processes [10]. In all FGD processes (except the SWFGD process), large quantities of chemical sorbents (limestone, lime, magnesium-enhanced lime, calcium hydroxide, etc.) are needed. Therefore, significant capital is required to acquire and transport those chemical sorbents and to acquire space for storage. Furthermore, most of these processes generate solid waste, such as gypsum, which needs space for storage and is expensive to dispose of. Meanwhile, the high costs and the apparent excessive fertilizer use from industrialized countries restrict the use of the ammonia FGD system [8].

As large amounts of water are needed for cooling, many power plants prefer to be built in coastal areas. Furthermore, due to its natural alkalinity and high availability, seawater has been considered as a technically and economically reliable solvent for desulfurization processes in coastal and marine applications [11]. In this technique, the absorbed $\mathrm{SO}_{2}$ is transformed into sulfate ions $\left(\mathrm{SO}_{4}{ }^{2-}\right)$ and completely dissolved in seawater; therefore, no solid waste is generated and no storage space needed [12]. Thus, the FGD process using seawater as the sorbent is convenient and economical, and a large amount of research is being conducted to this end, especially in FGD improvement as shown in Figure 1. It was observed that the high salinity of seawater (mainly $\mathrm{NaCl}$ ) further improved the $\mathrm{SO}_{2}$ absorption [13]. In general, SWFGD systems may achieve a $\mathrm{SO}_{2}$ removal efficiency of 85-98\% [8].

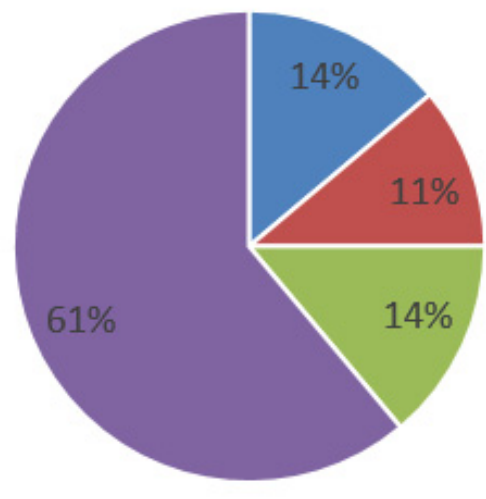

$$
\begin{aligned}
& \text { = Solubility/absorption equilibria = Modeling and simulation } \\
& \text { = Experiment } \quad \text { - Improvement }
\end{aligned}
$$

Figure 1. Percentage of articles mentioning the seawater flue gas desulfurization (SWFGD) process.

However, the SWFGD process has several drawbacks, such as its corrosive absorbent; low vapor loading capacity since $\mathrm{SO}_{2}$ has a lower solubility in seawater as compared to that in limestone or lime in conventional processes; high seawater flowrate; and large equipment size. Furthermore, many constraints have to be considered when designing the marine SWFGD process. Thus, many solutions have been proposed to increase the efficiency, capacity, and output of SWFGD processes as well as to make this process more compact and lighter due to the restriction of space and weight for marine applications. This paper aims to produce a comprehensive review of the development of SWFGD, which has recently received significant consideration and is suitable for flue gas treatment for coastal and naval applications, as well as enhancement methodologies of this process by investigating both open literature and patents. This work also discusses commercially advanced and intensified SWFGD, engineering issues, environmental impacts, current barriers, and perspectives on the research and development of advanced and intensified SWFGD processes. 


\section{Land-Based SWFGD Systems}

\subsection{Process Description}

The $\mathrm{SO}_{2}$ composition in the flue gas from power plants burning coal is on an average between 210 and $1540 \mathrm{ppm}_{\mathrm{v}}$ [11]. The typical $\mathrm{pH}$ of seawater varies from 7.6 to 8.4 with a temperature of between $5-15{ }^{\circ} \mathrm{C}$ [14]. The principle of SWFGD is the chemical absorption of $\mathrm{SO}_{2}$ by using seawater as a solvent because $\mathrm{SO}_{2}$ has much higher solubility as compared to other gases in flue gas. The reactions in the absorption of $\mathrm{SO}_{2}$ into seawater are as follows [2,7]:

Absorption:

$$
\mathrm{SO}_{2}+\mathrm{H}_{2} \mathrm{O} \leftrightarrow \mathrm{HSO}_{3}^{-}+\mathrm{H}^{+}
$$

Oxidation:

$$
\mathrm{HSO}_{3}^{-}+1 / 2 \mathrm{O}_{2} \leftrightarrow \mathrm{SO}_{4}^{2-}+\mathrm{H}^{+}
$$

Neutralization:

$$
\begin{aligned}
& \mathrm{HCO}_{3}^{-}+\mathrm{H}^{+} \leftrightarrow \mathrm{CO}_{2}+\mathrm{H}_{2} \mathrm{O} \\
& \mathrm{CO}_{3}^{2-}+2 \mathrm{H}^{+} \leftrightarrow \mathrm{CO}_{2}+\mathrm{H}_{2} \mathrm{O}
\end{aligned}
$$

Figure 2 shows a simplified open-loop FGD process and a simplified closed-loop FGD process. In open-loop mode, as shown in Figure 2a, raw seawater is pumped through the scrubber system to absorb the $\mathrm{SO}_{2}$ and neutralizes it with seawater's natural carbonate ions $\left(\mathrm{CO}_{3}{ }^{2-}\right)$ and bicarbonate ions $\left(\mathrm{HCO}_{3}{ }^{-}\right)$. The wash water is analyzed for turbidity, $\mathrm{pH}$, nitrates, and polycyclic aromatic hydrocarbons (PAH) [15]. In closed-loop mode, as shown in Figure 2b, seawater or freshwater is recirculated through the scrubber with no discharge to the sea. A water cleaning unit is required to clean discharged water. A heat exchanger is used for cooling the wash water before recycling the scrubber. In both the open and closed loops, the scrubber gas passes through a demister or mist eliminator to avoid entrained liquid droplets before entering a stack.

\subsection{New Developments}

Since solubility or absorption equilibrium of $\mathrm{SO}_{2}$ is essential and necessary to the design of scrubbers, several researchers measured the solubility of $\mathrm{SO}_{2}$. The solubility of $\mathrm{SO}_{2}$ in seawater in the range 10 to $25^{\circ} \mathrm{C}$ and $10^{-5}$ to 1 molal is predicted based on a simplified chemical model [16]. The predicted solubility of $\mathrm{SO}_{2}$ in seawater is approximately two to three times higher than that in freshwater. Two thermodynamic models using Bromley's model and Pitzer's model for $\mathrm{SO}_{2}$ solubility as a function of temperature (278.15-318.15 K) and $\mathrm{pH}$ were proposed [17].

In addition, the neutralization of seawater in the FGD process has been elucidated via experimental investigation and simulations [18]. To increase the $\mathrm{pH}$, a $\mathrm{NaOH}$ solution can also be used in the traditional SWFGD process [19]. However, the use of $\mathrm{NaOH}$ is expensive, leading to the high operating cost of SWFGD. Back et al. [20] proposed the use of discharged fly ash from a coal power plant for the increase and restoration of $\mathrm{pH}$ to reduce the operating cost. 


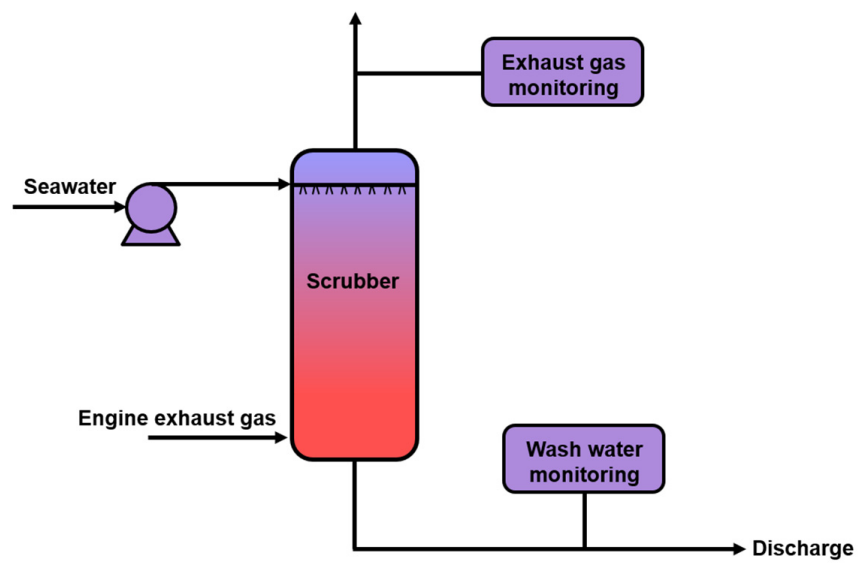

(a)

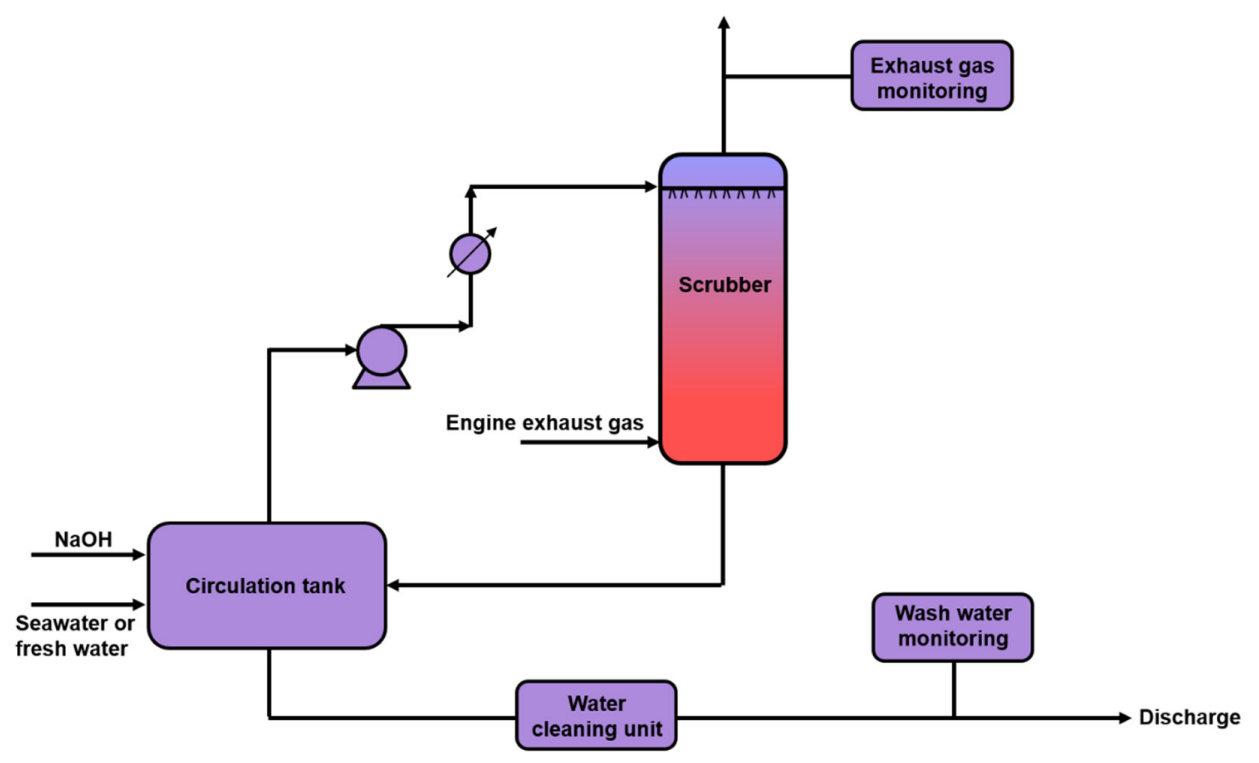

(b)

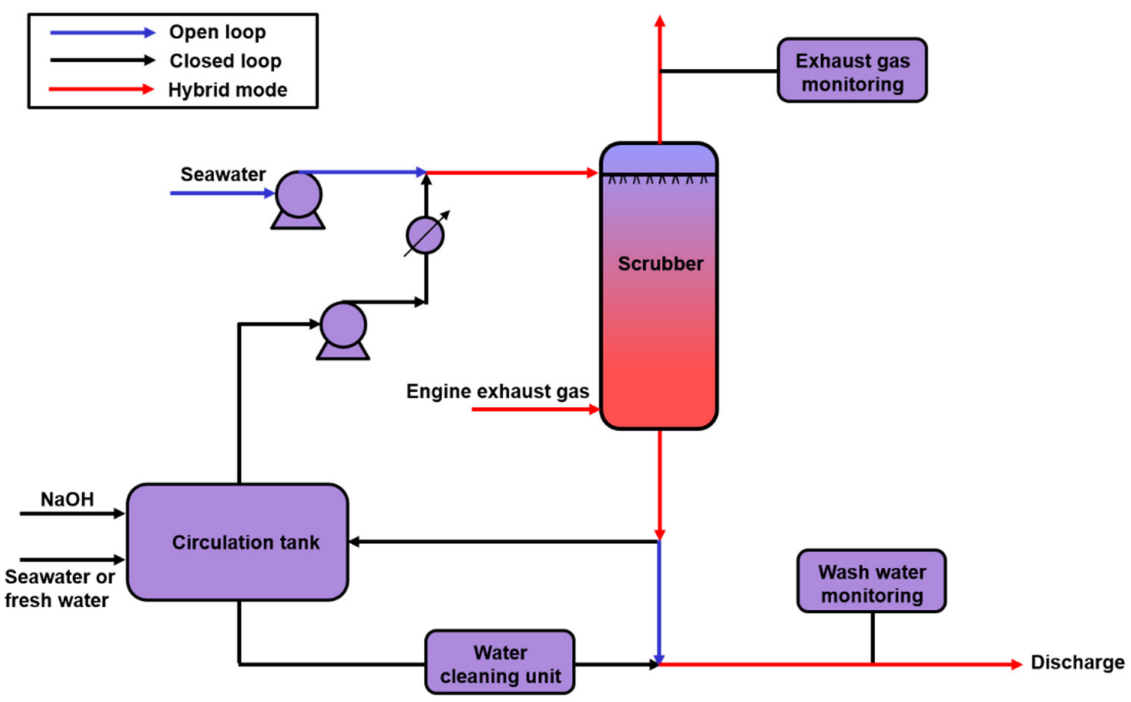

(c)

Figure 2. Schematic diagram of the (a) open-loop FGD process, (b) closed-loop FGD process, and (c) hybrid mode. 


\section{Marine SWFGD Systems}

As mentioned above, from 1 January 2020, all oceangoing vessels worldwide must comply with the $\mathrm{SO}_{x}$ emission requirement of the IMO. There are several solutions including using low-sulfur fuel, replacing the existing engine system with new one using liquefied natural gas (LNG), and installing a desulfurization system. Burning low-sulfur fuel reduces $\mathrm{SO}_{\mathrm{x}}$ emissions directly, but it has a very large impact on operating costs and issues related to cylinder wear due to the lower viscosity [21]. Meanwhile, using LNG, which has very low sulfur content, is also attractive due to abundant reserve, cheap cost, and environmentally-friendly products [22]. However, this solution requires a high investment cost, and it is difficult to change the engine system using oil to one using LNG. The third option is using a scrubber, which can use a low oil price. The installation of scrubbers is attractive because cleaner fuels are more expensive, especially in long-distance marine transportation [23].

\subsection{Characteristics of Marine SWFGD Process}

In general, $\mathrm{SO}_{2}$ in flue gas from existing ships has a typical range of concentrations of $80-1000 \mathrm{ppm}_{\mathrm{V}}$ dry basis [23,24]. Table 1 lists the differences in system design conditions of desulfurization processes between land-based and marine SWFGD [7].

Table 1. Differences in system design conditions of desulfurization processes between thermal power plants and large ships [7].

\begin{tabular}{ccc}
\hline & Thermal Power Plants & Large Ships \\
\hline Flue gas flow rate $\left(\mathrm{Nm}^{3} / \mathrm{h}\right)$ & 600,000 to $4,000,000$ & 23,000 to 540,000 \\
Inlet $\mathrm{SO}_{2}$ level $(\mathrm{ppmd})$ & 100 to 1800 & 700 \\
Outlet $\mathrm{SO}_{2}$ level $(\mathrm{ppmd})$ & 10 to 220 & 20 \\
& & $97.1(3.5 \% \mathrm{~S}$ to $0.1 \% \mathrm{~S}):$ SECAs \\
$\mathrm{SO}_{2}$ removal efficiency (\%) & 75 to 98 & $85.7(3.5 \%$ to $0.5 \%$ ): global sea \\
areas excluding SECAs \\
Regulatory items for seawater discharge & $\mathrm{pH}$, dissolved oxygen (DO), temperature, etc. & pH, PAH, turbidity, nitrates \\
\hline
\end{tabular}

The use of land-based scrubbers for marine applications has several challenges, such as the different legislative requirements, as mentioned above, and changing conditions when a ship sails through different waters [14]. Marine scrubbers have to be able to cope with changing seawater alkalinity (in case of seawater scrubbers), seawater temperature, and engine load. Furthermore, many constraints have to be considered when designing the marine SWFGD process. Besides constraints related to $\mathrm{SO}_{2}$ outlet and operating conditions in terms of liquid to gas (L/G), due to restrictions of column height, weight, and space, the column should be short, light, and compact [25]. If the column internal is required to achieve higher efficiency, columns should be designed to withstand motion, limiting the column height and making the packed-type columns more suitable than tray columns [26].

\subsection{Process Description}

Either an open loop or closed loop can be used for marine applications. Furthermore, a flexible or hybrid process (Figure 2c), which can switch between the open and closed-loop systems, can be considered. In the global sea area, the open loop is applied to reduce the operating cost and the closed loop is applied in regulated areas to satisfy the regulation [27]. According to DNV GL, 2625 out of the 3266 scrubbers systems being installed, or $80.3 \%$, are of the open-loop variety [28]. Hybrid systems account for 540 scrubber installations and closed-loop systems account for 65; the type of scrubber being fitted for 36 systems was unclear.

\subsection{New Developments}

Lamas et al. [29] numerically investigated the $\mathrm{SO}_{2}$ absorption in a spray column using seawater via a CFD model. Via experiment, it was found that a $47 \%$ reduction in seawater flow rate can be achieved when using packed scrubber [30]. Ion Iliuta and Iliuta [31] modeled $\mathrm{SO}_{2}$ seawater scrubbing 
in countercurrent packed-bed columns via an integrated approach. Many new approaches were proposed for SWFGD, such as using electrified sprays [32], structured packings [33], or rectangular (square) shape scrubbers [7] for improving the special needs of new systems. This will be described with more details in Section 4.

\section{Improvement of Water and SWFGD Systems}

Available SWFGD systems in coastal and commercial marine scrubbers normally consist of spray towers fed with pure seawater or seawater doped with caustic soda [6]. Spray towers are favorable when the pressure drop is critical [34] and a high separation degree is not required [35]. Furthermore, they possess lightweight, simple construction and operation, low investment, operating, and maintenance costs, and are applicable for gases with solid particles and precipitating solvents [36,37]. Furthermore, scrubber wash-water is commonly warm and acidic, and especially in open-loop systems where seawater is adopted, it has appreciable corrosion potential [6] that leads to the preference of simpler spray scrubber to packed ones.

However, spray towers have several disadvantages, such as low mass transfer rates and high pumping costs [38,39]. These units are often bulky and heavy constructions [23]. Due to the typical constraints of marine applications, mass transfer rates, seawater consumption, and scrubber size should be considered to improve during process design [6]. Thus, new approaches were suggested for improving the performance of spray columns, including process modifications, such as modification and optimization of operating conditions, improvement of spray and vapor distributors, adding column internals, using a square or rectangular shape, using pre-scrubber, and using multiple scrubber feed; process integration, such as combining treatment of $\mathrm{SO}_{\mathrm{x}}$ and other gases, and waste heat recovery; and process intensification, such as the use of electrified sprays, swirling gas flow, and rotating packed beds (shown in Figure 3).
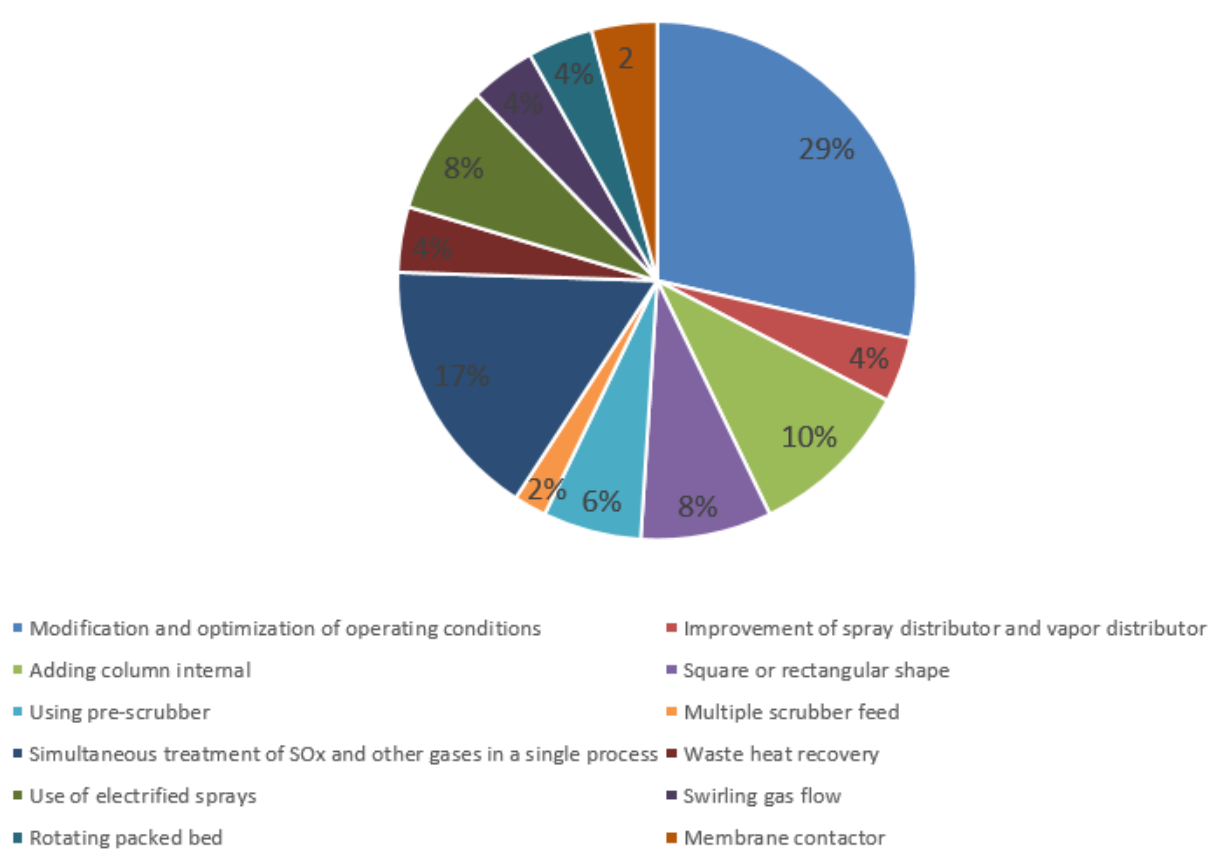

Figure 3. Percentage of articles mentioning different solutions for improving SWFGD process.

\subsection{Modification and Optimization of Operating Conditions}

Operating pressure

SWFGD can be operated at atmospheric pressure due to the high solubility of $\mathrm{SO}_{2}$ in water, and even higher operating pressure is favorable for scrubber efficiency [40]. Additionally, due to 
the turbocharger in engines, the flue gas already has atmospheric pressure leading to back pressure in the system. This back pressure may influence engine performance, leading to an increase in fuel consumption, particulate matter (PM) and CO emissions, and exhaust temperature [41]. An increase in $\mathrm{NO}_{x}$ emissions is also possible due to the increase in engine load [42].

Operating temperature

Higher temperatures of absorption solution have negative desulfurization effects, i.e., lower operating temperature is theoretically favorable for enhancing the $\mathrm{SO}_{2}$ removal efficiency. Nonetheless, the influence of absorption temperature within $20-40{ }^{\circ} \mathrm{C}$ is insignificant [43]. To enhance the absorption, the use of a venturi scrubber for quenching the flue gas and heat exchanger used for cooling seawater can be considered. As seawater with a temperature between $5-15^{\circ} \mathrm{C}$ is used for cooling, the scrubber can be operated at $25-35^{\circ} \mathrm{C}$.

pHcondition

The $\mathrm{pH}$ of seawater, which normally varies from 7.6 to 8.4 , can be considered to enhance $\mathrm{SO}_{2}$ removal efficiency. It is to be more useful to add $\mathrm{NaOH}$ to the same absorption seawater feed to support $\mathrm{SO}_{2}$ removal while preserving a wash-water $\mathrm{pH}$ level close to neutral [11].

Effect of gas flow or gas velocity on desulfurization

Experimental results by Schmidt and Stichlmair [44] indicated that the gas velocity is of little importance for the transfer rate, at least in systems with high reaction rates or small liquid-side resistances $\left(\mathrm{SO}_{2} / \mathrm{NaOH}\right.$ and air/water, respectively). It should be noted that quadrupling the gas velocity from 5 to $20 \mathrm{~m} / \mathrm{s}$ and keeping the gas/liquid ratio (G/L) constant means a fourfold increased throughput. By investigating the gas velocity up to $5 \mathrm{~m} / \mathrm{s}$, Wang et al. [45] found that the removal efficiency and absorbent $\mathrm{pH}$ of $\mathrm{SO}_{2}$ decreased with the increase in gas flow. More study is required to find the most efficient gas velocity for a $\mathrm{SO}_{2}$ scrubber to minimize the scrubber size, which is required for off-shore scrubbers.

Effect of liquid-to-gas ratio on desulfurization

When the $\mathrm{L} / \mathrm{G}$ increases at a fixed volume of gas, the volume of the liquid rises in the column, leading to a higher contact gas-liquid area [6,11]. As a result, higher $\mathrm{SO}_{2}$ removal efficiency can be achieved, especially in the spray column [46]. Meanwhile, the pressure drop also increases with the increase of $\mathrm{L} / \mathrm{G}[45]$.

Effect of seawater salinity and seawater alkalinity

Caiazzo et al. [47] indicated that seawater scrubbing $\mathrm{SO}_{2}$ performed better than distilled water because of its inherent alkalinity. The absorption capacity of $\mathrm{SO}_{2}$ reduces when both alkalinity and salinity decreases [18]. It was also observed that the high salinity of the seawater can improve $\mathrm{SO}_{2}$ absorption [13]. Zhao et al. [48] claimed that at the same alkalinity, the effect of salinity is negligible, while the solubility of sulfur dioxide increases distinctly with the increasing alkalinity.

Effect of partial pressure of $\mathrm{SO}_{2}$

Zhang et al. [43] found that the strength of the factors arranged according to their influence on the removal efficiency of $\mathrm{SO}_{2}$ is liquid-gas ratio $>$ gas-flow rate $>$ inlet concentration of $\mathrm{SO}_{2}>$ temperature of absorption solution. Additionally, a lower inlet partial pressure of $\mathrm{SO}_{2}$ leads to a higher removal efficiency of $\mathrm{SO}_{2}$. Ma et al. [49] pointed out that the $\mathrm{pH}$ of tailwater decreases and the desulfurization capacity of seawater increases upon increasing the partial pressure of $\mathrm{SO}_{2}$. 
Effect of use of additives

The addition of an additive is an important method to increase the removal efficiency of $\mathrm{SO}_{2}[43,50]$. Although many researchers have performed studies on the influence of additives on the limestone/lime-gypsum FGD [51-54], research on the effects of additives on seawater desulfurization is lacking [43]. Lower concentrations of inorganic additives (magnesium sulfate and sodium sulfate) increase the removal efficiency of $\mathrm{SO}_{2}$ and have little effect on desulfurization seawater recovery $[43,55]$. Organic additives (acetic acid and hexanedioic acid) promote seawater desulfurization at lower $\mathrm{pH}$, but they have negative effects on post-desulfurization seawater recovery. Additional research and development are needed to reduce the investment and operation costs for the process.

\subsection{Improvement of Spray and Vapor Distributors}

Spray and vapor distributors have to be considered to achieve adequate hydraulics in the inlet area. Failure to achieve this may result in low separation efficiency, premature flooding, and excessive entrainment [56]. Uniform vapor and liquid distribution allow maximum capacity and efficiency for a given tower design [57]. The quality of the spray distributor depends on several factors, such as the nozzle pattern, nozzle construction, spray angle, and height of the spray nozzles above the bed [56]. Uniformity of spray, small drop size with high velocity, and low atomization energy are the desired criteria for an atomizer [58,59].

The vapor distributor location is very important because if it is too low, it can be submerged in the bottom liquid, leading to turbulence on the liquid level, high pressure drop, and liquid entrainment into the rising vapor. The vapor distributor should not be close to the maximum liquid level; there should be space between them [56]. Note that a minimum liquid level at the bottom is also important because, if it is too low or the difference between column bottom edge and minimum liquid level is small, the vapor from a vapor distributor can partly release from the bottom of the column. Furthermore, the vapor flow from the distributor should not impinge on the bottom liquid surface, which can occur when an internal pipe is "elled" down, or if the column inlet pipe slopes downward at the entrance [56].

\subsection{Adding Column Internals}

Reconsidering structured packings, which can create a larger contact area for gas and liquid phases leading to higher separation efficiency, was suggested for improving marine scrubbers [60], provided that there are space-saving improvements of the scrubbers. Recently, findings were reported on the performance of two different SWFGD units including packed column and spray column [6]. The results indicated that the packed column can save $70 \%$ in terms of water requirement compared to spray towers. Recently, fourth-generation packing, which offers several advantages, such as high capacity, low pressure drop, and reduced costs [61], has been employed for marine SWFGD [31]. Systems with perforated plates benefit from extremely vigorous gas-liquid transfer, whereas packing uses a larger gas-liquid interfacial area. Recently, a combination of packings and perforated plates can achieve high $\mathrm{SO}_{2}$ removal efficiency while reducing the absorber size and seawater consumption [2].

\subsection{Square or Rectangular Shape}

A cylinder shape is mostly used for small shop assembled columns and for pressurized columns, while a square shape could be considered when the absorber is operated at low pressure [35]. Square-based shapes have been widely used for coal boiler flue gas desulfurization systems, achieving a higher volumetric efficiency than that of existing cylindrical scrubbers [7]. The reason for this is because, with the same area, the diameter of the cylindrical scrubber is larger than the side of the square shape scrubber. With this shape, field erection and packing installation are simplified [35] and space can be reduced. However, it is difficult to obtain good flue gas distribution with this shape [62]. Note that other equipment and devices such as heat exchanger, pump, and tank are the same as those in 
cylindrical desulfurization system. Recently, PacificGreen Technologies developed a compact, flexible rectangular shape that creates the smallest possible footprint without compromising on efficiency [63].

\subsection{Using Pre-Scrubber}

The outlet gas temperature is normally high, which is $120-130{ }^{\circ} \mathrm{C}$ from power plants utilizing coal [2] and from 385 to $490^{\circ} \mathrm{C}$ from diesel engines [64,65]. Note that different exhaust temperatures correspond to different engine loads [66]. Low temperatures favor absorption, i.e., higher solubility is measured at low temperatures $[67,68]$. This reduces the solvent flow rate required to absorb a given amount of $\mathrm{SO}_{2}$. Thus, high-temperature flue gas must be cooled before entering the scrubbing gas. Reduced temperature is also used for system protection and allows the scrubber to be smaller since the volume flow rate of flue gas is smaller.

Hansen [14] invented a method using two scrubber sections for the removal of $\mathrm{SO}_{2}$ from the exhaust gas of a marine engine. The exhaust gas is quickly cooled from a temperature of approximately $180-250{ }^{\circ} \mathrm{C}$ to a temperature range of approximately $45-60{ }^{\circ} \mathrm{C}$ in the first scrubber section before entering the second scrubber section. Alfa Laval $\mathrm{SO}_{\mathrm{x}}$ scrubber combines a jet scrubber used to cool flue gas by using water and an absorber where the $\mathrm{SO}_{\mathrm{x}}$ is removed to the required level (as shown in Figure 4) [69].

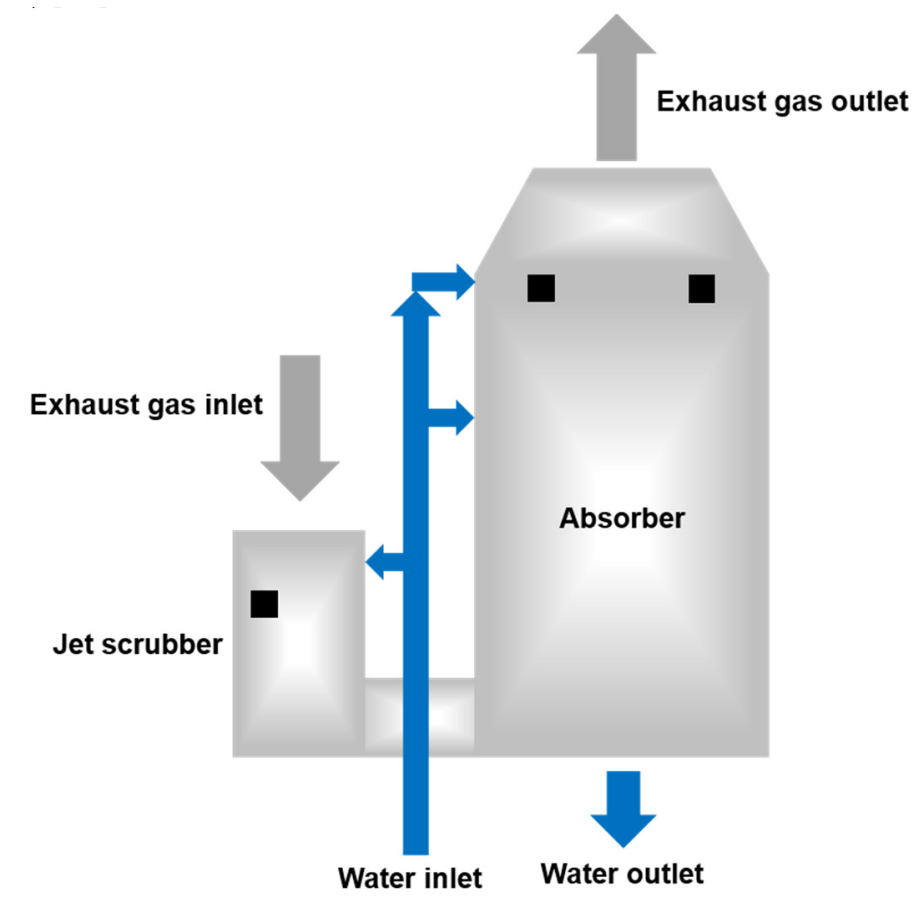

Figure 4. Schematic configuration combining a jet scrubber and an absorber [69].

The jet scrubber could be replaced by a venturi scrubber [70] to increase PM trapping, but this increases the pressure drop across the unit. Venturi scrubbers are also used as a cooler to quench hot flue gases (up to $1000^{\circ} \mathrm{C}$ ) [71]. Using a venturi scrubber for quenching (rapid cooling) leads to decreasing the volume flow rate because the volume is affected by temperature. This leads to a higher capacity of the scrubber. Furthermore, a venturi scrubber can remove $\mathrm{SO}_{2}$, leading to higher efficiency of the whole system in terms of $\mathrm{SO}_{2}$ removal.

\subsection{Multiple Scrubber Feed}

$\mathrm{SO}_{2}$ scrubbers also have a similar phenomenon for $\mathrm{CO}_{2}$ absorption: absorption mainly takes place in the bottom section, while very little absorption occurs in the upper section of the absorber [72]. In $\mathrm{CO}_{2}$ absorption, the lean amine stream can be split to achieve higher separation efficiency, with most 
of the amine charged near the bottom of the column, where a large flow rate can carry large amounts of acid gas in the first few stages [73,74]. $\mathrm{SO}_{2}$ absorption from flue gas also has a similar phenomenon; thus, this solution can be applied for improving $\mathrm{SO}_{2}$ removal efficiency [45]. In particular, in a multiple feed configuration, (see Figure 5) there needs to be more than one solvent feed, with a large portion of seawater enters near the bottom of the scrubber to remove most of the $\mathrm{SO}_{2}$ in that section as well as to reduce the flue gas temperature, leading to higher removal efficiency.

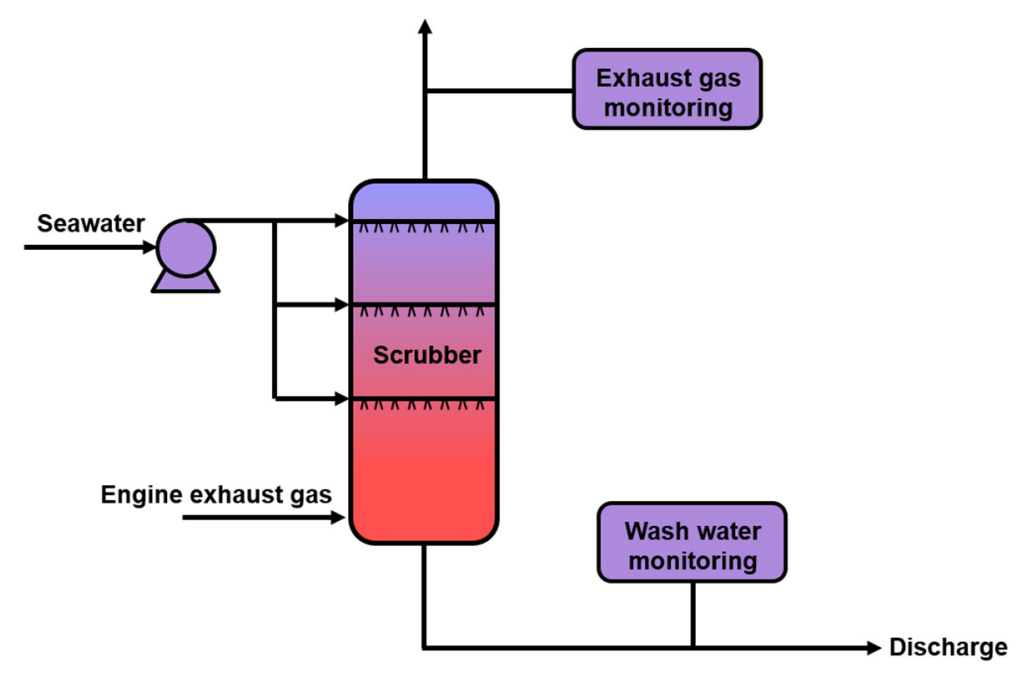

Figure 5. Schematic diagram of a multiple scrubber feed.

\subsection{Simultaneous Treatment of $\mathrm{SO}_{x}$ and Other Gases in a Single Process}

$\mathrm{NO}_{\mathrm{x}}$, mainly produced from the combustion of $\mathrm{N}_{2}$ and $\mathrm{O}_{2}$ in air [75], can be removed using the two most popular methodologies, exhaust gas recirculation (EGR) and selective catalytic reduction (SCR). Meanwhile, for $\mathrm{CO}_{2}$ removal or capture, chemical absorption using a solvent is one of the most popular technologies. Due to different removal methodology and mechanism, removal of $\mathrm{SO}_{2}$ and other gases such as $\mathrm{NO}_{x}$ or $\mathrm{CO}_{2}$ is accomplished with high treatment efficiency in different independent equipment. Such a system has drawbacks, such as the requirement for a large installation area [76], a complex system [77], and high investment and operation costs [78]. Integrating the treatment of $\mathrm{SO}_{\mathrm{x}}$ with other gases is expected to be more compact and reduce investment and operating costs. Therefore, many studies have focused on the simultaneous removal of $\mathrm{SO}_{2}$ with $\mathrm{NO}_{\mathrm{x}}$ and/or $\mathrm{CO}_{2}$ in a single process via wet scrubbing [79-83]. Recently, a concept of simultaneous removal of $\mathrm{SO}_{\mathrm{x}}$ and $\mathrm{NO}_{\mathrm{x}}$ using seawater was developed by Yara Marine Technology [84].

\subsection{Waste Heat Recovery}

One of the drawbacks of wet scrubbers is that the heat contained in the exhaust gas is wasted [18]. Thus, a waste heat recovery system based on organic Rankine cycle (ORC), which vaporizes a working fluid expanding through a turbine in order to generate electricity, or Kalina cycle, which is an absorption power cycle, was proposed to improve overall energy efficiency onboard ships [85-88]. Figure 6 shows a schematic diagram of a simple ORC $[85,89]$. The first ORC onboard a ship is currently being tested on the newly built MV Figaro providing a maximum output power of $0.5 \mathrm{MW}$ [90]. Note that the pressure drop needs to be checked carefully since the exhaust gas pressure is almost atmospheric pressure. Additional developments are required before the concept can be applied onboard marine ships. 


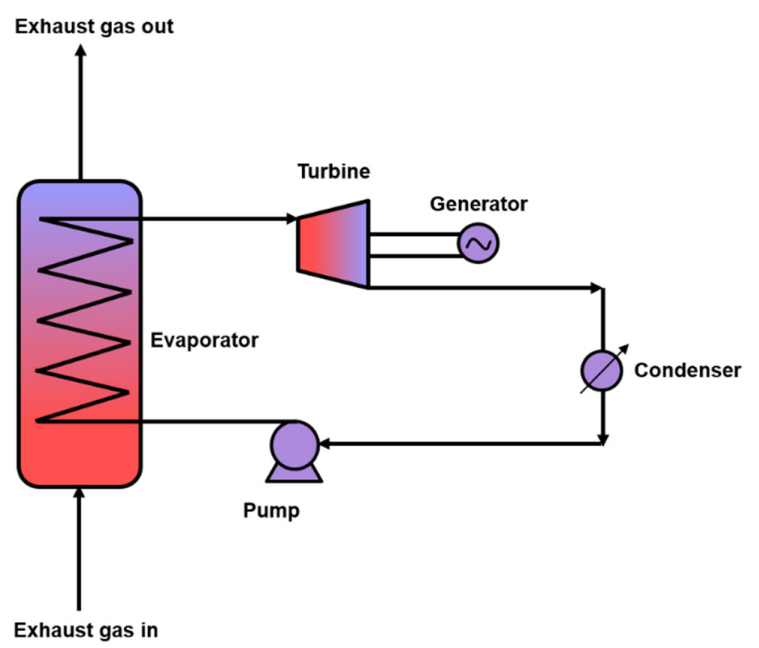

Figure 6. Schematic diagram of a simple organic Rankine cycle.

\subsection{Use of Electrified Sprays}

Electrification is associated with an appreciable improvement of $\mathrm{SO}_{2}$ absorption rate with low supplementary costs and can be a candidate for innovative spray tower absorbers [91]. Similar phenomena occur during thunderstorms when scavenging of gases and aerosols are enhanced by the electric charge of raindrops. Several researchers studied electrified water spray absorption of $\mathrm{SO}_{2}$ to improve spray generation and droplet dispersion. Di Natale et al. [32] found that the mass transfer rate for charged droplets was 1.57 times higher than that of uncharged droplets. Recently, Di Natale et al. [92] tested a laboratory-scale wet electrostatic scrubber using distilled water sprays with flow rates from 2 to $6 \mathrm{~mL} / \mathrm{min}$, electrified by contact charging with a potential up to $5 \mathrm{kV}$.

\subsection{Swirling Gas Flow}

Mass transfer between the gas and liquid phases in spray towers can be enhanced using the concept of swirling gas flow [39]. With this solution, the flue gas also has a longer retention time in the scrubber, leading to longer contact time. Figure 7 shows the schematic diagram of a $\mathrm{SO}_{\mathrm{x}} \mathrm{scrubber}$ system with swirling gas flow [93]. Schrauwen and Thoenes [94] studied mass transfer in a co-current spray tower with swirling gas flow by introducing the gas tangentially into the tower. More recently, Javed et al. [39] investigated the augmentation of mass transfer in a spray tower using swirling gas flow. Swirling gas flow leads to an increased retention time and compact scrubber, which is suitable for offshore applications.

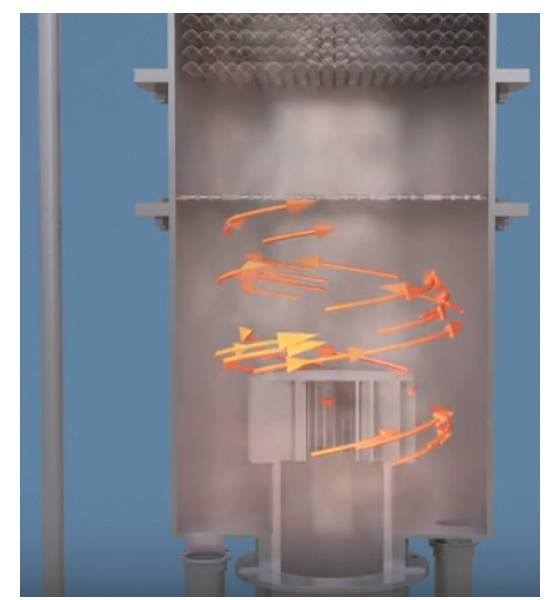

Figure 7. Schematic diagram of a $\mathrm{SO}_{\mathrm{x}}$ scrubber system with swirling gas flow [93]. 


\subsection{Rotating Packed Bed}

A rotating packed bed (RPB) generating high acceleration via centrifugal force, leading to the formation of thin liquid films and tiny liquid droplets through a centrifugal acceleration, was invented to enhance the gas-liquid mass transfer [95]. Rao et al. [96] presented the potential of RPB for distillation and absorption, the most commonly applied separation unit operations. Substantial reduction in terms of volume or space can be achieved using Higee as compared to conventional packed beds [97]. The $\mathrm{SO}_{2}$ removal efficiency was improved using a RPB [98]. Recently, $\mathrm{SO}_{2}$ absorption intensification by an ionic liquid in a rotating packed bed was investigated [99]. Future investigations such as experiments on a wider range of $\mathrm{SO}_{2}$ concentrations and for seawater with different $\mathrm{pH}$ and alkalinity, development of model and design tool, and mitigation of liquid maldistribution [100] are necessary to make this solution more viable.

\subsection{Membrane Contactor}

Another advanced technology that can be considered is membrane contactor, which can realize gas-liquid contacting operation through the hollow fiber membrane. In this technology, the absorbent liquid flows on one side and the gas flows on the other side of the membrane [101]. Due to several advantages including high interfacial area per unit volume, absence of emulsion, no flooding at high flow rates, and high corrosion resistance [102], several studies investigated the application of membrane contactor for $\mathrm{SO}_{2}$ removal. Sun et al. [103] focused on a membrane contactor scrubber and showed that the mass transfer coefficient in seawater is about twice of the $\mathrm{NaOH}$ solution with $\mathrm{pH}$ 8.35. Recently, Liu et al. [104] introduced air bubbles to seawater to increase the fluid turbulence at the gas-liquid interface near the membrane surface, which could reduce the mass transfer resistance of the liquid film or improve the mass transfer. In particular, the overall mass transfer coefficient of $\mathrm{SO}_{2}$ could be increased from $1.15-1.5 \times 10^{-3} \mathrm{~m} / \mathrm{s}$ without aeration to $1.35-1.85 \times 10^{-3} \mathrm{~m} / \mathrm{s}$ with $5 \mathrm{~L} / \mathrm{min}$ aeration flowrate.

\section{Recently Commercialized Advanced and Intensified SWFGD Systems}

The first scrubber in the world installed onboard a ship by Aalborg Industries A/S has been in operation since June 2010 [14]. This hybrid scrubber can operate in either a seawater mode or in a fresh water mode. From that time, much effort has been undertaken to improve the performance of SWFGD listed in Section 4. In this section, several recently commercialized advanced and intensified SWFGD systems, which simultaneously satisfy regulations, high efficiency, and low space requirement, were briefly surveyed. Mitsubishi Hitachi Power Systems, Ltd. has developed a rectangular FGD system, leading to improved installation layout [7]. In Korea, Hanbal Masstech Ltd. located in Gimhae has patented compact, flexible square-shaped FGD units creating the smallest possible footprint (as shown in Figure 8) as explained in Section 4.

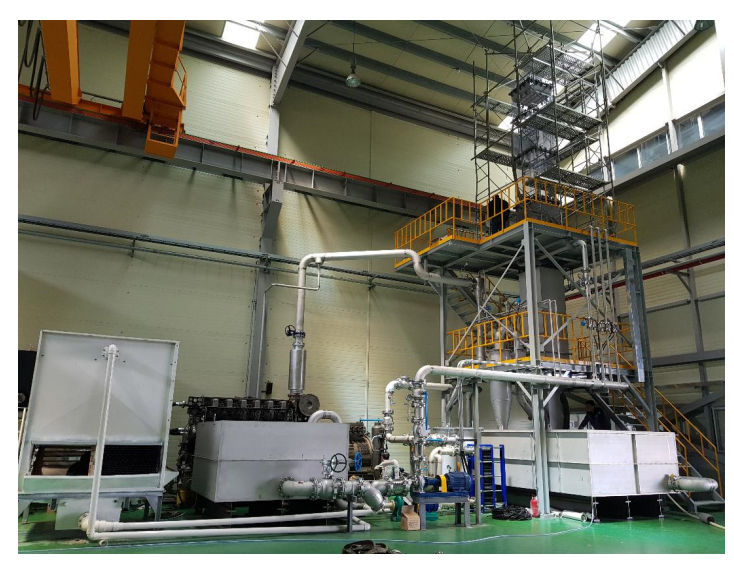

Figure 8. Hanbal Masstech's $\mathrm{SO}_{2}$ scrubber. 
In addition, $\mathrm{SO}_{\mathrm{x}}$ scrubbers made by Fuji Electric uses cyclone technology in their internal structure. This can efficiently bring the seawater (or alkaline chemicals) and exhaust gas into contact by generating a vortex in the exhaust gas and spraying seawater from the pipes arranged spirally (as shown in Figure 9) [105]. It can be easily applied to existing ships with limited installation space, and the loss of loading space by mounting the system can also be reduced.

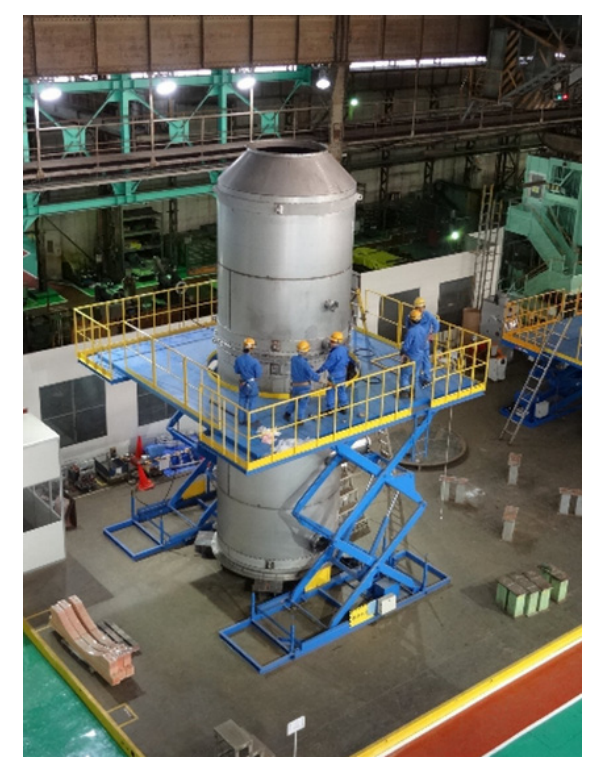

Figure 9. $\mathrm{SO}_{\mathrm{x}}$ scrubber using cyclone technology [105].

\section{Engineering Issues}

a. Scrubber has corrosion potential due to the acidic environment [6]; thus, selecting appropriate corrosion and wear-resistant material is crucial. Two-phase (duplex) stainless steel is mainly used for the scrubber tower [7] because it can perform well in corrosive environments [106].

b. Pressure drop related to the column auxiliaries (demister, gas distributor, piping, etc.) [6] should be low in scrubbers because flue gas has a similar pressure as the atmosphere. In case the excessive exhaust backpressure occurs, it can result in additional fuel consumption and other issues such as lower turbocharger efficiency, increased component temperatures, increased wear, and increased $\mathrm{NO}_{\mathrm{x}}$ emission [106].

c. Important factors such as droplet size, nozzle material, nozzle spray pattern and placement, nozzle connection size and type, required scrubbing fluid flow rates, and pressure drop need to be considered when selecting a marine scrubbing spray nozzle for proper absorption [107].

$\mathrm{d}$. The scrubber on the ship should be flexible as a ship travels to different areas, which can have different regulations. Thus, a hybrid system should be considered.

e. Marine engines emit PM that has a complex nature, being composed of carbonaceous particles [23], especially the soot particles related to severe pathologies [108]. Electrostatic precipitator, wet scrubber, venturi scrubber, cyclone, in which the dust is collected, can be considered as a PM control device $[109,110]$. Further technologies can be referred to in Table 6 in the paper by Natale and Carotenuto [23].

f. In the closed-loop systems, salt and PM accumulation may need to be discharged, as crystallized solids may plug the pipe and pump. Bleeding off scrubber water from the system and adding seawater or fresh water to replace the lost volume can be considered [69]. The $\mathrm{SO}_{4}{ }^{2-}$ concentration in industrial effluents is set ranging from 250 to $500 \mathrm{mg} / \mathrm{L}$ in many countries [111,112]. The $\mathrm{SO}_{4}{ }^{2-}$ concentration in the waste and treated water tank needs to be checked and the discharge sulfate ion concentration needs to be calculated to remain in the allowable range. Depending on the $\mathrm{SO}_{4}{ }^{2-}$ concentration, $\mathrm{SO}_{4}{ }^{2-}$ may not need to be treated; alternatively, it can be treated using several technologies, such as biological or 
chemical treatment [113-124]. In addition, in case a water cleaning unit is needed to clean bleed-off water, the addition of a coagulant can be considered [69].

g. The amount of oxygen from flue gas and seawater is generally not sufficient for complete oxidation of $\mathrm{HSO}_{3}{ }^{-}$(and $\mathrm{SO}_{3}{ }^{2-}$ ) to $\mathrm{SO}_{4}{ }^{2-}$. This can be accomplished by using a blower to supply air into the bottom of the SWFGD [2].

h. Seawater can be added to the neutralization tank to dilute the mixture so that it can be discharged $[2,19]$.

i. The seawater $\mathrm{pH}$ can decrease to a range of 2.5-3 after absorbing $\mathrm{SO}_{2}$ from flue gas [18]. However, according to the 2015 IMO Guidelines, the effluent water should be no lower than 6.5 before it is discharged. To increase the $\mathrm{pH}, \mathrm{a} \mathrm{NaOH}$ solution can be employed in SWFGD [20].

\section{Environmental Impacts}

Despite the positive effect of the use of scrubbers to reduce atmospheric pollution, questions have been raised on their potential impacts on the marine environment [125]. The use of scrubbers results in a shift of the environmental impact of sulfur from emissions to the atmosphere toward a direct discharge into aquatic systems [126]. When the wash water from open-loop scrubbers is thrown back into the sea, the discharged $\mathrm{SO}_{\mathrm{x}}$ is neutralized by the seawater alkalinity. This contributes to the acidification of the ocean and affects the marine carbonate cycle [127]. This process adds up to the ongoing ocean acidification resulting from the increase in atmospheric $\mathrm{CO}_{2}$ injections to the sea related to the increase in $\mathrm{CO}_{2}$ concentration in the atmosphere. Negative effects of ocean acidification on coral reefs and limestone-requiring organisms have already been observed and are well known [127]. Moreover, decreasing $\mathrm{pH}$ from around 8 to 6.5 will cause the desorption of massive amounts of carbon dioxide from the seawater, adding to the carbon dioxide emissions from the engine exhaust. This partly motivates IMO to initiate the approval process for the ship-based $\mathrm{CO}_{2}$ capture.

Furthermore, together with high sulfur emissions, these scrubbers are known to result in higher emissions of other hazardous species including metals and PAHs [126]. In addition, the discharged water has a biochemical oxygen demand (BOD), leading to a reduction of oxygen in the local environment and a negative effect on the local marine environment [110].

\section{Challenges and Future Perspectives}

The equilibrium data at low $\mathrm{SO}_{2}$ concentrations, needed to design SWFGD, are still scarce [11]. Furthermore, there is a need to explore additives enhancing the removal efficiency of $\mathrm{SO}_{2}$. In addition, with many constraints to be considered when designing marine SWFGD processes and the trend for improving the process performance in terms of process compactness, reducing the scrubber weight, energy efficiency, lower seawater consumption, and process intensification can be an attractive solution. To achieve the development of solutions for process intensification for scrubbers, future investigations such as the development of models for the description of intensified scrubbers and the development of design tools are essential and necessary to support the implementation of intensified systems.

Research is still needed to find out the most efficient gas velocity for a $\mathrm{SO}_{2}$ scrubber to minimize the scrubber size, which is essential for off-shore scrubbers. Due to limited space on a ship, methodologies for the simultaneous removal of $\mathrm{SO}_{2}$ and other gases can be considered as a good future direction. Furthermore, to achieve better hydraulic performance for improving $\mathrm{SO}_{2}$ removal efficiency, high-performance spray and vapor distributors need to be developed. In addition, techno-economic and life cycle analysis of marine SWFGD versus land-based SWFGD are needed for future works.

\section{Conclusions}

Considering the globally stricter IMO environmental regulations, in this paper, the current research and industrial applications of SWFGD were successfully investigated and analyzed. SWFGD can be considered as a technically and economically reliable unit operation for fossil fuel combustion 
plants and marine applications, owing to its natural alkalinity and the large availability, simplicity of its process design and operation, no requirement of chemical sorbent, production of no solid waste, and relatively high removal efficiency. Many solutions using the concept of process modification, integration, and intensification to improve the performance of SWFGD were critically evaluated. It was found that several advanced and intensified scrubber systems have been commercialized, leading to many benefits, such as higher compactness, lower weight, higher energy efficiency, and lower seawater consumption. However, to achieve the smooth development of solutions for process enhancement and intensification for scrubbers, future investigations are necessary on the development of equilibrium data for a wider range of $\mathrm{SO}_{2}$ concentrations, models for the description of advanced and intensified scrubbers, and the development of design tools.

Author Contributions: N.V.D.L. and D.Y.L. designed the paper, conducted the literature review, and wrote the paper. K.M.J., K.C., L.Y.M., and L.S.W. advised process improvement. N.V.D.L. and M.L. conceived the core concepts for the research and provided academic advice. All authors collaborated for the preparation, revisions, and general editing of this manuscript. All authors have read and agreed to the published version of the manuscript.

Funding: This work was supported by the Basic Science Research Program through the National Research Foundation of Korea (NRF) funded by the Ministry of Education (2018R1A2B6001566), the Priority Research Centers Program through the National Research Foundation of Korea (NRF) funded by the Ministry of Education (2014R1A6A1031189), and by the "Human Resources Program in Energy Technology" of the Korea Institute of Energy Technology Evaluation and Planning (KETEP) from the Ministry of Trade, Industry and Energy, the Republic of Korea (No. 20204010600100).

Conflicts of Interest: The authors declare no conflict of interest.

\section{References}

1. Soud, H.N.; Wu, Z. East Asia-Air Pollution Control and Coal-Fired Power Generation; IEACCC/06; International Energy Agency (IEA), IEA Coal Research: London, UK, 1998.

2. Oikawa, K.; Yongsiri, C.; Takeda, K.; Harimoto, T. Seawater flue gas desulfurization: Its technical implications and performance results. Environ. Prog. 2003, 22, 67-73. [CrossRef]

3. Zhang, C.; Yang, L. One-dimensional simulation of synergistic desulfurization and denitrification processes for electrostatic precipitators based on a fluid-chemical reaction hybrid model. Energies 2018, 11, 3249. [CrossRef]

4. Nielsen, R.F.; Haglind, F.; Larsen, U. Design and modeling of an advanced marine machinery system including waste heat recovery and removal of sulphur oxides. Energy Convers. Manag. 2014, 85, 687-693. [CrossRef]

5. Wan, Z.; Zhu, M.; Chen, S.; Sperling, D. Three steps to a green shipping industry. Nature 2016, 530, $275-277$. [CrossRef]

6. Flagiello, D.; Parisi, A.; Lancia, A.; Carotenuto, C.; Erto, A.; Di Natale, F. Seawater desulphurization scrubbing in spray and packed columns for a 4.35 MW marine diesel engine. Chem. Eng. Res. Des. 2019, 148, 56-67. [CrossRef]

7. Sasaki, R.; Nagayasu, T.; Shingu, T.; Watanabe, Y.; Mori, T.; Sakurai, H. Practical design of marine $\mathrm{SO}_{\mathrm{x}}$ scrubber for mega-container ships. Mitsubishi Heavy Ind. Tech. Rev. 2019, 56, 1-8.

8. Córdoba, P. Status of Flue Gas Desulphurisation (FGD) systems from coal-fired power plants: Overview of the physic-chemical control processes of wet limestone FGDs. Fuel 2015, 144, 274-286. [CrossRef]

9. Srivastava, R.K.; Jozewicz, W.; Singer, C. $\mathrm{SO}_{2}$ scrubbing technologies: A review. Environ. Prog. 2001, 20, 219-228. [CrossRef]

10. Srivastava, R.K. Controlling SO2 Emissions: A Review of Technologies (EPA/600/R-00/093); U.S. Environmental Protection Agency: Washington, DC, USA, 2000.

11. Flagiello, D.; Erto, A.; Lancia, A.; Di Natale, F. Experimental and modelling analysis of seawater scrubbers for sulphur dioxide removal from flue-gas. Fuel 2018, 214, 254-263. [CrossRef]

12. Zhang, Y.; Gao, Y.H.; Wang, G.D.; Li, C.Y.; Zhou, J.T. Seawater flue gas desulfurization and post-desulfurization seawater recovery. Adv. Mater. Res. 2011, 233-235, 662-666. [CrossRef] 
13. Millero, F.J.; Hershey, P.; Johnson, G. The solubility of $\mathrm{SO}_{2}$ and the dissociation of $\mathrm{H}_{2} \mathrm{SO}_{3}$ in $\mathrm{NaCl}$ solutions. J. Atmos. Chem. 1989, 8, 377-389. [CrossRef]

14. Hansen, J.P. Scrubber System and Method Technical Field. WO 2013/045272 A1, 4 April 2013.

15. ENVI-MARINETM Scrubber Technology. Available online: https://maritechgroup.com/exhaust-gas-cleaningsystem/\#tab-1-2 (accessed on 1 April 2020).

16. Abdulsattar, A.H.; Sridhar, S.; Bromley, L.A. Thermodynamics of the sulfur dioxide-seawater system. Alche J. 1977, 23, 62-68. [CrossRef]

17. Rodriguez-Sevilla, J.; Alvarez, A.; Diaz, M.C.; Marrero, M.C. Absorption equilibria of dilute $\mathrm{SO}_{2}$ in seawater. J. Chem. Eng. 2004, 49, 1710-1716.

18. Andreasen, A.; Mayer, S. Use of Seawater scrubbing for $\mathrm{SO}_{2}$ removal from marine engine exhaust gas. Energy Fuels 2007, 21, 3274-3279. [CrossRef]

19. Tokumura, M.; Baba, M.; Znad, H.T.; Kawase, Y.; Yongsiri, C.; Takeda, K. Neutralization of the acidified seawater effluent from the flue gas desulfurization process: Experimental investigation, dynamic modeling, and simulation. Ind. Eng. Chem. Res. 2006, 45, 6339-6348. [CrossRef]

20. Back, S.; Mojammal, A.H.M.; Jo, H.; Kim, J.; Jeong, M.; Seo, Y.; Joung, H.; Kim, S. Increasing seawater alkalinity using fly ash to restore the $\mathrm{pH}$ and the effect of temperature on seawater flue gas desulfurization. J. Mater. Cycles Waste Manag. 2019, 21, 962-973. [CrossRef]

21. Brynolf, S.; Magnusson, M.; Fridell, E.; Andersson, K. Compliance possibilities for the future ECA regulations through the use of abatement technologies or change of fuels. Transp. Res. Part D 2014, 28, 6-18. [CrossRef]

22. Ibrahim, S.S.; Elgohary, M.M. Eco-friendly selection of ship emissions reduction strategies with emphasis on SOx and NOx emissions. Int. J. Nav. Archit. Ocean Eng. 2014, 6, 737-748.

23. Di Natale, F.; Carotenuto, C. Particulate matter in marine diesel engines exhausts: Emissions and control strategies. Transp. Res. Part D Transp. Environ. 2015, 40, 166-191. [CrossRef]

24. EPA. Analysis of Commercial Marine Vessels Emissions and Fuel Consumption Data; EPA: Washington, DC, USA, 2000.

25. Lee, S.G.; Long, N.V.D.; Lee, M. Design and optimization of natural gas liquefaction and recovery processes for offshore floating liquefied natural gas plants. Ind. Eng. Chem. Res. 2012, 51, 10021-10030. [CrossRef]

26. Long, N.V.D.; Lee, M. Advances in Distillation Retrofit, 1st ed.; Springer: New York, NY, USA, 2017.

27. ENVI-Marine ${ }^{\mathrm{TM}}$ Exhaust Gas Scrubbing Systems. Available online: https://www.pacificgreen-marine.com/ envi-marine (accessed on 1 April 2020).

28. $80 \%$ of Scrubbers are Open-Loop: DNV, GL. Available online: https://www.seatrade-maritime.com/asia/80scrubbers-are-open-loop-dnv-gl (accessed on 1 April 2020).

29. Lamas, M.I.; Rodriguez, C.G.; Rodriguez, J.D.; Telmo, J. Numerical model of $\mathrm{SO}_{2}$ scrubbing with seawater applied to marine engines. Pol. Marit. Res. 2016, 23, 42-47. [CrossRef]

30. Vidal, F.; Ollero, P.; Ortiz, F.J.G.; Villanueva, A. Catalytic seawater flue gas desulfurization process: An experimental pilot plant study. Environ. Sci. Technol. 2007, 41, 7114-7119. [CrossRef] [PubMed]

31. Iliuta, I.; Iliuta, M.C. Modeling of $\mathrm{SO}_{2}$ seawater scrubbing in countercurrent packed-bed columns with high performance packings. Sep. Purif. Technol. 2019, 226, 162-180. [CrossRef]

32. Di Natale, F.; Carotenuto, C.; Lancia, A. Enhanced $\mathrm{SO}_{2}$ removal by using charged water droplets. Chem. Eng. Trans. 2016, 52, 505-510.

33. Darake, S.; Rahimi, A.; Hatamipour, M.S.; Hamzeloui, P. $\mathrm{SO}_{2}$ removal by seawater in a packed-bed tower: Experimental study and mathematical modeling. Sep. Sci. Technol. 2014, 49, 988-998. [CrossRef]

34. Yeh, N.K.; Rochelle, G.T. Liquid-phase mass transfer in spray contactors. AiChE J. 2003, 49, $2363-2373$. [CrossRef]

35. Feron, P. Absorption-Based Post-Combustion Capture of Carbon Dioxide; Woodhead Publishing: Cambridge, UK, 2016.

36. Bandyopadhyay, A.; Biswas, M.N. $\mathrm{CO}_{2}$ capture in a spray column using a critical flow atomizer. Sep. Purif. Technol. 2012, 94, 104-114. [CrossRef]

37. Seyboth, O.; Zimmermann, S.; Heidel, B.; Scheffknecht, G. Development of a spray scrubbing process for post combustion $\mathrm{CO}_{2}$ capture with amine based solvents. Energy Procedia 2014, 63, 1667-1677. [CrossRef]

38. Coulson, J.M.; Richardson, J.F. Chemical Engineering Volume 2, 3rd ed.; Pergamon Press: Oxford, UK, 1980.

39. Javed, K.H.; Mahmud, T.; Purba, E. Enhancement of mass transfer in a spray tower using swirling gas flow. Chem. Eng. Res. Des. 2006, 84, 465-477. [CrossRef] 
40. Towler, G.; Sinnott, R.K. Chemical Engineering Design_Principles, Practice and Economics of Plant and Process Design, Butterworth-Heinemann; Elsevier: Burlington, MA, USA, 2013.

41. Jaaskelainen, H. Engine Exhaust Back Pressure. Diesel Net Technology Guide. 2007. Available online: https://dieselnet.com/tech/diesel_exh_pres.php (accessed on 1 April 2020).

42. ABS Advisory on Exhaust Gas Scrubber Systems, July 2018. Available online: https://ww2.eagle.org/content/ dam/eagle/advisories-and-debriefs/exhaust-gas-scrubber-systems-advisory.pdf (accessed on 1 April 2020).

43. Zhang, Y.; Gao, Y.; Zhou, J. Effects of Additives on Seawater Flue Gas Desulfurization. In 2011 International Conference on Environment Science and Engineering IPCBEE; IACSIT Press: Singapore, 2011; Volume 8, pp. 119-123.

44. Schmidt, B.; Stichlmair, J. Two-phase flow and mass transfer in scrubbers. Chem. Eng. Tech. 1991, 14, 162-166. [CrossRef]

45. Wang, Z.; Peng, Y.; Ren, X.; Gui, S.; Zhang, G. Absorption of sulfur dioxide with sodium hydroxide solution in spray columns. Ind. Eng. Chem. Res. 2015, 54, 8670-8677. [CrossRef]

46. Flagiello, D.; Natale, F.D.; Carotenuto, C.; Erto, A.; Lancia, A. Seawater desulphurization of simulated flue gas in spray and packed columns: An experimental and modelling comparison. Chem. Eng. Trans. 2018, 69, 799-804.

47. Caiazzo, G.; Langella, G.; Miccio, F.; Scala, F. An experimental investigation on seawater $\mathrm{SO}_{2}$ scrubbing for marine application. Environ. Prog. Sustain. Energy 2013, 36, 1179-1186. [CrossRef]

48. Zhao, X.; Hou, C.; Fan, L.; Cui, Z. Absorption of sulfur dioxide by seawater and concentrated seawater. Chin. J. Environ. Eng. 2013, 7, 3123-3130.

49. Ma, Y.; Xu, L.; Su, P.; Feng, D.; Yang, K. Study on seawater scrubbing for $\mathrm{SO}_{2}$ removal from ship's power plant exhaust gas. Environ. Prot. Eng. 2020, 46, 31-47.

50. Cao, H.W.; Dong, F. Study status of additives for efficient sulfur retention in FGD. Energy Conserv. Technol. 2003, 21, 10-12.

51. Wang, J.G.; Hu, J.B.; Duan, Z.Y.; Chen, Z.Q. The application of compound additives in two kinds of flue-gas desulfurization process. J. Eng. Energy Power 2006, 21, 93-95.

52. Liu, S.Y.; Liu, P.; Gao, J.; Liu, J.Y.; Ye, Z.X.; Xu, C.H. Simulation studies on limestone dissolution with organic acid additives in limestone-based flue gas desulfurization. In Proceedings of the 2nd International Conference on Bioinformatics and Biomedical Engineering (ICBBE 2008), Shanghai, China, 16-18 May 2008; pp. 3899-3902.

53. Dahlan, I.; Lee, K.T.; Amaruddin, A.H.; Mohamed, A.R. Evaluation of various additives on the preparation of rice husk ash (RHA)/CaO-based sorbent for flue gas desulfurization (FGD) at low temperature. J. Hazard. Mater. 2009, 161, 81-83. [CrossRef]

54. Zhai, L.Z.; Zhong, Q.; He, C. Experimental research on effect of acids as additives on wet flue gas desulfurization with ethylenediamine. In Proceedings of the International Conference on Energy and Environment Technology (ICEET '09), Guilin, China, 16-18 October 2009; pp. 327-331.

55. Chu, X.F.; Tian, J.R.; Sun, B.H.; Chen, G.L.; Ding, F.J. Pilot research on demonstration project of desulphurization via white clay and sea-water. Environ. Eng. 2009, 27, 81-83.

56. Kister, H.Z. Distillation Operation; McGraw-Hill: New York, NY, USA, 1989.

57. Aly, F.A.; Yeung, S.Y. High Efficiency Radial Type Vapor Distributor for Packed Towers. U.S. Patent 4810428A, 7 March 1989.

58. Bandyopadhyay, A.; Biswas, N.B. Critical flow atomizer in $\mathrm{SO}_{2}$ spray scrubbing. Chem. Eng. J. 2008, 139, 29-41. [CrossRef]

59. Biswas, M.N. Atomization in two-phase critical flow. In Proceedings of the 2nd International Conference on Liquid Atomization and Spray Systems-II, Madison, WI, USA, 20-24 June 1982; pp. 145-151.

60. Flagiello, D.; Di Natale, F.; Erto, A.; Lancia, A. Marine diesel engine flue gas desulphurization by seawater scrubbing in a structured packing absorption column. In Proceedings of the 40th ASICI, Rome, Italy, 7-9 June 2017.

61. Schultes, M. Raschig Super-Ring-A new fourth generation packing offers new advantages. Chem. Eng. Res. Des. 2003, 81, 48-57. [CrossRef]

62. Just, P.E. Shell Cansolv deploying CCS worldwide. In Proceedings of the Second Post-Combustion Capture Conference (PCCC2), Bergen, Norway, 17-20 September 2013. 
63. How Does It work? Available online: https://www.pacificgreen-marine.com/envi-marine/how-does-it-work (accessed on 1 April 2020).

64. Wang, Z.; Kuang, H.; Zhang, J.; Chu, L.; Ji, Y. Experimental study on the removal of real exhaust pollutants from a diesel engine by activated carbon. Appl. Sci. 2019, 9, 3175. [CrossRef]

65. Peng, S. Ship Flue Gas Desulfurization Method and Equipment. U.S. Patent 8,038,774 B2, 8 October 2011.

66. Kasper, A.; Aufdenblatten, S.; Forss, A.; Mohr, M.; Burtscher, H. Particulate emissions from a low-speed marine diesel engine. Aerosol Sci. Technol. 2007, 41, 24-32. [CrossRef]

67. Al-Enezi, G.; Ettouney, H.; El-Dessouky, H.; Fawzi, N. Solubility of sulfur dioxide in seawater. Ind. Eng. Chem. Res. 2001, 40, 1434-1441. [CrossRef]

68. Qi, Y.; Hu, X.; Liu, Y.; Sun, D.; Li, R.; Zhu, H. Highly efficient and reversible absorption of $\mathrm{SO}_{2}$ by hydroxyl ammonium ionic liquids at low partial pressure. J. Chem. Technol. Biotechnol. 2019, 94, 3325-3332. [CrossRef]

69. Emission Project Guide, MAN B\&W Two-Stroke Marine Engines. Available online: https://indico.cern. ch/event/659434/attachments/1528657/2391369/MAN_BW_Two-stroke_Marine_Engines.pdf (accessed on 1 April 2020).

70. Product Guide-SOx Scrubber Technology. Available online: https://cdn.wartsila.com/docs/default-source/ product-files/egc/product-guide-o-env-sox-scrubber-tech.pdf (accessed on 1 April 2020).

71. Venturi Scrubber. Available online: https:/emis.vito.be/en/bat/tools-overview/sheets/venturi-scrubber (accessed on 1 April 2020).

72. Polasek, J.C.; Bullin, J.A.; Donnelly, S.T. Alternative Flow Schemes to Reduce Capital and Operating Costs of Amine Sweetening Units. In Proceedings of the 1982 AIChE Spring National Meeting, New York, NY, USA, 1982; American Institute of Chemical Engineers: New York, NY, USA, 1982.

73. Lyddon, L.; Nguyen, H. Analysis of various flow schemes for sweetening with amines. In Proceedings of the 78th GPA Annual Convention, Nashville, TN, USA, 2-3 March 1999; pp. 177-184.

74. Cho, H.; Binns, M.; Min, K.J.; Kim, J.K. Automated process design of acid gas removal units in natural gas processing. Comp. Chem. Eng. 2015, 83, 97-109. [CrossRef]

75. Zhoua, J.; Wang, H. Study on efficient removal of SOx and NOx from marine exhaust gas by wet scrubbing method using urea peroxide solution. Chem. Eng. J. 2020, 390, 124567. [CrossRef]

76. Park, H.W.; Choi, S.; Park, D.W. Simultaneous treatment of $\mathrm{NO}$ and $\mathrm{SO}_{2}$ with aqueous $\mathrm{NaClO}_{2}$ solution in a wet scrubber combined with a plasma electrostatic precipitator. J. Hazard. Mater. 2015, 285, 117-126. [CrossRef]

77. Chu, H.; Chien, T.W.; Li, S.Y. Simultaneous absorption of $\mathrm{SO}_{2}$ and $\mathrm{NO}$ from flue gas with $\mathrm{KMnO}_{4} / \mathrm{NaOH}$ solutions. Sci. Total Environ. 2001, 275, 127-135. [CrossRef]

78. Jin, D.S.; Deshwal, B.R.; Park, Y.S.; Lee, H.K. Simultaneous removal of $\mathrm{SO}_{2}$ and NO by wet scrubbing using aqueous chlorine dioxide solution. J. Hazard. Mater. 2006, 135, 412-417. [CrossRef]

79. Chien, T.W.; Chu, H.; Hsueh, H.T. Kinetic study on absorption of $\mathrm{SO} 2$ and $\mathrm{NOx}$ with acidic $\mathrm{NaClO}_{2}$ solutions using the spraying column. J. Environ. Eng. 2003, 129, 967-974. [CrossRef]

80. Hutson, N.D.; Kryzynska, R.; Srivastava, R. Simultaneous removal of $\mathrm{SO}_{2}, \mathrm{NO}_{\mathrm{x}}$ and $\mathrm{Hg}$ from coal flue gas using a $\mathrm{NaClO}_{2}$-enhanced wet scrubber. Ind. Eng. Chem. Res. 2008, 47, 5825-5831. [CrossRef]

81. Pillai, K.C.; Chung, S.J.; Raju, T.; Moon, I.S. Experimental aspects of combined $\mathrm{NO}_{\mathrm{x}}$ and $\mathrm{SO}_{2}$ removal from flue-gas mixture in an integrated wet scrubber-electrochemical cell system. Chemosphere 2009, 76, 657-664. [CrossRef] [PubMed]

82. Pourmohammadbagher, A.; Jamshidi, E.; Ale-Ebrahim, H.; Dabir, S. Study on simultaneous removal of $\mathrm{NO}_{x}$ and $\mathrm{SO}_{2}$ with $\mathrm{NaClO}_{2}$ in a novel swirl wet system. Ind. Eng. Chem. Res. 2011, 50, 8278-8284. [CrossRef]

83. Puxty, G.; Wei, S.C.; Feron, P.; Meuleman, E.; Beyad, Y.; Burns, R.; Maeder, M. A novel process concept for the capture of CO2 and SO2 using a single solvent and column. Energy Procedia 2014, 63, 703-714. [CrossRef]

84. Ibrahim, S. Process Evaluation of a SOx and NOx Exhaust Gas Cleaning Concept for Marine Application; Department of Energy and Environment, Chalmers University of Technology Gothenburg: Gothenburg, Sweden, 2016.

85. Singh, D.V.; Pedersen, E. A review of waste heat recovery technologies for maritime applications. Energy Convers. Manag. 2016, 111, 315-328. [CrossRef]

86. Viking Line, Viking Grace First Ship to Install New Swedish Heat Recovery System. Available online: https://www.vikingline.com/globalassets/documents/market_specific/corporate/press/ pressreleaseeng/2014/20141201-climeon-eng.pdf (accessed on 14 June 2020). 
87. Marinelog, Maersk Vessel First with New Waste Heat Recovery System-Marine Log. Available online: http://www.marinelog.com/index.php?option=com_k2\&view=item\&id=10842\%253Amaersk-vesselfirstwith-new-waste-heat-recovery-system\&Itemid=231 (accessed on 14 June 2020).

88. Ng, C.W.; Tam, I.C.K.; Wu, D. Thermo-economic performance of an organic rankine cycle system recovering waste heat onboard an offshore service vessel. J. Mar. Sci. Eng. 2020, 8, 351. [CrossRef]

89. Shu, G.; Liang, Y.; Wei, H.; Tian, H.; Zhao, J.; Liu, L. A review of waste heat recovery on two-stroke IC engine aboard ships. Renew. Sustain. Energy Rev. 2012, 19, 385-401. [CrossRef]

90. Green Car Congress, First Reference Installation of Opcon Waste Heat Recovery Technology for Ships; Potential for 5-10\% Fuel Savings. Available online: https:/www.greencarcongress.com/2012/08/opcon-20120826.html (accessed on 23 June 2020).

91. Di Natale, F.; Carotenuto, C.; Manna, L.; Lancia, A. Chemi-electro-hydrodynamic of sulphur dioxide absorption by electrified water sprays. Chem. Eng. Trans. 2018, 69, 685-690.

92. Di Natale, F.; Carotenuto, C.; Caserta, S.; Troiano, M.; Manna, L.; Lancia, A. Experimental evidences on the chemi-electro-hydrodynamic absorption of sulphur dioxide in electrified water sprays. Chem. Eng. Res. Des. 2019, 146, 249-262. [CrossRef]

93. ANY SOx scubber system. Available online: http://www.anytech.co.kr/index.php?ver=PCver (accessed on 23 June 2020).

94. Schrauwen, F.J.M.; Thoenes, D. Selective gas absorption in a cyclone spray scrubber. Chem. Eng. Sci. 1988, 43, 2189-2194. [CrossRef]

95. Mallinson, R.H.; Ramshaw, C. Mass Transfer Process. U.S. Patent 4,283,255, 11 August 1981.

96. Rao, D.P.; Bhowal, A.; Goswami, P.S. Process intensification in rotating packed beds (Higee): An appraisal. Ind. Eng. Chem. Res. 2004, 43, 1150-1162. [CrossRef]

97. Long, N.V.D.; Minh, L.Q.; Luis, P.; Lee, M. Intensified distillation-based separation processes: Recent developments and perspectives. Chem. Eng. Technol. 2016, 39, 2183-2195. [CrossRef]

98. Liangliang, Z.; Shuying, W.; Yue, G.; Baochang, S.; Yong, L.; Haikui, Z.; Guangwen, C.; Jianfeng, C. Absorption of $\mathrm{SO}_{2}$ with calcium-based solution in a rotating packed bed. Sep. Purif. Technol. 2019, 214, 148-155.

99. Liu, Y.Z.; Wu, W.; Liu, Y.; Li, B.B.; Luo, Y.; Chu, G.W.; Zuo, H.W.; Chen, J.F. Desulfurization intensification by ionic liquid in a rotating packed bed. Chem. Eng. Process. 2020, 148, 107793. [CrossRef]

100. Hacking, J.A.; Delsing, N.F.E.J.; de Beer, M.M.; van der Schaaf, J. Improving liquid distribution in a rotating packed bed. Chem. Eng. Process. 2020, 149, 107861. [CrossRef]

101. Karoor, S.; Sirkar, K.K. Gas-absorption studies in microporous hollow fiber membrane modules. Ind. Eng. Chem. Res. 1993, 32, 674-684. [CrossRef]

102. Zhang, Q.; Cussler, E.L. Microporous hollow fibers for gas-absorption. 1. Mass-transfer in the liquid. J. Membr. Sci. 1985, 23, 321-332.

103. Sun, X.; Meng, F.; Yang, F. Application of seawater to enhance $\mathrm{SO}_{2}$ removal from simulated flue gas through hollow fiber membrane contactor. J. Membr. Sci. 2008, 312, 6-14. [CrossRef]

104. Liu, J.; Deng, M.; Yuan, J.; Ji, Z.; Zhao, Y.; Guo, X. An aeration membrane absorption seawater flue gas desulfurization process intensified by combining dual-phase flow and oxidation reaction. Chem. Eng. Process. 2020, 153, 107935. [CrossRef]

105. Fuji Electric's First Shipment of Exhaust Gas Cleaning Systems for Ships. Available online: https://www.fujielectric-europe.com/en/fuji/news/news_detail/n/fuji_electric_s_first_shipment_of_ exhaust_gas_cleaning_systems_for_ships (accessed on 1 April 2020).

106. Practical Considerations for the Installation and Operation of Exhaust Gas Cleaning Systems. 2019. Available online: https://www.standard-club.com/media/3229390/abs_scrubber-guidance.pdf (accessed on 1 April 2020).

107. Marine FGD Gas Scrubbing/Cleaning Nozzles. Available online: https://www.bete.com/applications/ marinescrubbing (accessed on 1 April 2020).

108. International Agency for Research on Cancer, 2012. IARC: Diesel Engine Exhaust Carcinogenic. Available online: https://www.iarc.fr/wp-content/uploads/2018/07/pr213_E.pdf (accessed on 1 April 2020).

109. Hesketh, E. Air Pollution Control, Traditional and Hazardous Pollutants; Technomic Publishing AG: Lancaster, PA, USA, 1996.

110. Poullikkas, A. Review of design, operating, and financial considerations in flue gas desulfurization systems. Energy Technol. Pol. 2015, 2, 92-103. [CrossRef] 
111. Silva, A.M.; Lima, R.M.F.; Leao, V.A. Mine water treatment with limestone for sulfate removal. J. Hazard. Mater. 2012, 221-222, 45-55. [CrossRef] [PubMed]

112. Fang, P.; Tang, Z.; Chen, X.; Huang, J.; Tang, Z.; Cen, C. Removal of high-concentration sulfate ions from the sodium alkali FGD wastewater using ettringite precipitation method: Factor assessment, feasibility, and prospect. J. Chem. 2018, 2008, 1265168. [CrossRef]

113. Najib, T.; Solgi, M.; Farazmand, A.; Heydarian, S.M.; Nasernejad, B. Optimization of sulfate removal by sulfate reducing bacteria using response surface methodology and heavy metal removal in a sulfidogenic UASB reactor. J. Environ. Chem. Eng. 2017, 5, 3256-3265. [CrossRef]

114. Kiran, M.G.; Pakshirajan, K.; Das, G. Heavy metal removal from multicomponent system by sulfate reducing bacteria: Mechanism and cell surface characterization. J. Hazard. Mater. 2017, 324, 62-70. [CrossRef] [PubMed]

115. Lu, H.; Zou, W.; Chai, P.; Wang, J.; Bazinet, L. Feasibility of antibiotic and sulfate ions separation from wastewater using electrodialysis with ultra-filtration membrane. J. Clean. Prod. 2016, 112, 3097-3105. [CrossRef]

116. Hong, S.Q.; Cannon, F.S.; Hou, P.; Byrne, T.; Nieto-Delgado, C. Adsorptive removal of sulfate from acid mine drainage by polypyrrole modified activated carbons: Effects of polypyrrole deposition protocols and activated carbon source. Chemosphere 2017, 184, 429-437. [CrossRef]

117. Calinescu, O.; Marin, N.M.; Ionita, D.; Pascu, L.F.; Tudorache, A.; Surpăteanue, G.; Badea, I.A.; Aboul-Enein, H.Y. Selective removal of sulfate ion from different drinking waters. Environ. Nanotechnol. Monit. Manag. 2016, 6, 164-168. [CrossRef]

118. Arahman, N.; Mulyati, S.; Lubis, M.R.; Takagi, R.; Matsuyama, H. Removal profile of sulfate ion from mix ion solution with different type and configuration of anion exchange. J. Water Process Eng. 2017, 20, 173-179. [CrossRef]

119. Tait, S.; Clarke, W.P.; Keller, J.; Batstone, D.J. Removal of sulfate from high-strength wastewater by crystallization. Water Res. 2009, 43, 762-772. [CrossRef]

120. Luna, M.D.G.; Rance, D.P.M.; Bellotindos, L.M.; Lu, M.C. Removal of sulfate by fluidized bed crystallization process. J. Env. Chem. Eng. 2017, 5, 2431-2439. [CrossRef]

121. Benatti, C.T.; Tavares, C.R.G.; Lenzi, E. Sulfate removal from waste chemicals by precipitation. J. Environ. Manag. 2009, 90, 504-511. [CrossRef] [PubMed]

122. Runtti, H.; Luukkonen, T.; Niskanen, M.; Tuomikoski, S.; Kangas, T.; Tynjälä, P.; Tolonen, E.; Sarkkinen, M.; Kemppainen, K.; Rämö, J.; et al. Sulphate removal over barium-modified blast-furnace-slag geopolymer. J. Hazard. Mater. 2016, 317, 373-384. [CrossRef] [PubMed]

123. Kartic, D.N.; Narayana, B.C.A.; Arivazhagan, M. Removal of high concentration of sulfate from pigment industry effluent by chemical precipitation using barium chloride: RSM and ANN modeling approach. J. Env. Manag. 2018, 206, 69-76. [CrossRef]

124. Dou, W.X.; Zhou, Z.; Jiang, L.M.; Jiang, A.; Huang, R.; Tian, X.; Zhang, W.; Chen, D. Sulfate removal from wastewater using ettringite precipitation: Magnesium ion inhibition and process optimization. J. Environ. Manag. 2017, 196, 518-526. [CrossRef]

125. Dulière, V.; Baetens, K.; Lacroix, G. Potential Impact of Wash Water Effluents from Scrubbers on Water Acidification in the Southern North Sea; Royal Belgian Institute of Natural Sciences: Bruxelles, Belgium, 2020.

126. Teuchies, J.; Cox, T.J.S.; Itterbeeck, K.V.; Meysman, F.J.R.; Blust, R. The impact of scrubber discharge on the water quality in estuaries and ports. Environ. Sci. Eur. 2020, 32, 103. [CrossRef]

127. Turner, D.R.; Edman, M.; Gallego-Urrea, J.A.; Claremar, B.; Hassellöv, I.; Omstedt, A.; Rutgersson, A. The potential future contribution of shipping to acidification of the Baltic Sea. Ambio 2018, 47, 368-378. [CrossRef]

Publisher's Note: MDPI stays neutral with regard to jurisdictional claims in published maps and institutional affiliations. 